\title{
The Mathematical Traveler
}

\section{Exploring the}

Grand History of Numbers 


\section{The Mathematical Traveler Exploring the Grand History of Numbers}

\section{CALVIN C. CLAWSON}

Springer Science+Business Media, LLC 


\section{Library of Congress Cataloging in Publication Data}

Clawson, Calvin C.

The mathematical traveler: exploring the grand history of numbers / Calvin C. Clawson.

p. $\quad \mathrm{cm}$.

Includes bibliographical references and index.

1. Numeration. 2. Counting. I. Title.

QA141.C52 1994

94-2740

513.2-dc20

CIP

ISBN 978-0-306-44645-0 ISBN 978-1-4899-6014-6 (eBook)

DOI 10.1007/978-1-4899-6014-6

(C) 1994 Calvin C. Clawson

Originally published by Plenum US in 1994.

Softcover reprint of the hardcover 1st edition 1994

All rights reserved

No part of this book may be reproduced, stored in a retrieval system, or transmitted in any form or by any means, electronic, mechanical, photocopying, microfilming, recording, or otherwise, without written permission from the Publisher 
To my wife, Susan 


\title{
Acknowledgments
}

\begin{abstract}
Many people helped to make this book a reality. Special thanks go to my workshop friends who patiently reviewed the manuscript and offered many excellent suggestions: Marie Edwards, Bruce Taylor, Linda Shephard, Phyllis Lambert, and Brian Herbert. I also want to thank my professors at the University of Utah, in both the Departments of Philosophy and Mathematics for their care and dedication in teaching me to love mathematics.
\end{abstract}




\section{Contents}

INTRODUCTION

CHAPTER 1 How Do We Count?

CHAPTER 2 Early Counting

CHAPTER 3 Counting in Other Species

CHAPTER 4 Ancient Numbers

CHAPTER 5 Chinese and New World Numbers

CHAPTER 6 Problems in Paradise

CHAPTER 7 The Negative Numbers

CHAPTER 8 Dealing with the Infinite

CHAPTER 9 Dedekind's Cut: Irrational Numbers 
CHAPTER 10 Story of $\pi$ : Transcendental Numbers

CHAPTER 11 Expanding the Kingdom: Complex Numbers

CHAPTER 12 Really Big: Transfinite Numbers

Glossary

Bibliography

Index 